\title{
Functional Recovery of Rare Case of Sciatic Nerve Schwannoma with Peripheral Nerve Block and without Intraoperative Neurophysiological Monitoring
}

\author{
Jefri Henky, ${ }^{1}$ Ahmad Faried ${ }^{2}$ \\ ${ }^{1}$ Department of Neurosurgery and Spine, Faculty Medicine of Baiturrahmah University/ \\ Semen Padang Hospital Padang, Indonesia, ${ }^{2}$ Department of Neurosurgery Faculty of Medicine \\ Universitas Padjadjaran/Dr. Hasan Sadikin General Hospital Bandung, Indonesia
}

\begin{abstract}
Schwannoma are benign peripheral nerve tumors derived from the Schwann cells in the neural sheath. Sciatic nerve schwannoma in the lower extremity is uncommon, accounting for only $1 \%$ of all schwannoma cases. This report aimed to describe the functional recovery after lower limb surgery of sciatic nerve schwannoma with peripheral nerve block and without intraoperative neurophysiological monitoring (IOM) performed in Semen Padang Hospital in 2019. A 78-year-old woman presented with a complaint of pain on her slowly growing mass at the right popliteal region, which had existed for 22 years. Microsurgical resection was performed with local peripheral nerve block and without intraoperative neurophysiological monitoring. Tumor was removed en-bloc by sharp dissection using a microscope without any complication. The patient had significant pain relief without any neurologic deficit three weeks after the surgery.
\end{abstract}

Key words: Functional recovery, intraoperative neurophysiological monitoring, neurologic deficit, peripheral nerve block, sciatic nerve schwannoma

\section{Penyembuhan Secara Fungsi Kasus Langka Schwannoma Saraf Sciatic dengan Blok Saraf Perifer tanpa Pemantauan Neurofisiologis Intraoperatif}

\begin{abstract}
Abstrak
Schwannoma adalah tumor saraf tepi jinak yang berasal dari sel Schwann dalam selubung saraf. Pada ekstremitas bawah, schwannoma saraf sciatic jarang terjadi, terhitung 1\% dari semua schwannoma. Laporan ini bertujuan menggambarkan pemulihan fungsional dengan blok saraf perifer setelah operasi tungkai bawah schwannoma saraf sciatic tanpa pemantauan neurofisiologis intraoperatif (IOM) di Rumah Sakit Semen Padang, 2019. Seorang wanita 78 tahun datang dengan keluhan nyeri pada massa yang tumbuh perlahan di daerah popliteal kanannya selama 22 tahun. Reseksi bedah mikro dilakukan dengan blok saraf perifer secara lokal dan tanpa pemantauan neurofisiologis intraoperatif. Tumor terangkat secara en-bloc dengan diseksi tajam menggunakan mikroskop tanpa ada komplikasi. Pada minggu ketiga pascaoperasi, pasien mengalami pengurangan rasa sakit yang signifikan tanpa defisit neurologis.
\end{abstract}

Kata kunci: Blok saraf perifer, defisit neurologi, penyembuhan secara fungsi, pemantauan neurofisiologis intra-operatif, schwannoma saraf sciatic

Corresponding Author: Jefri Henky, Department of Neurosurgery and Spine, Semen Padang Hospital Jalan Bypass KM 07, Pisang, Pauh, Padang, West Sumatera, Indonesia, Email: neurosurg_henky@yahoo.co.id 


\section{Introduction}

Schwannoma, also known as neurilemoma or neurinoma, are benign peripheral nerve tumors derived from Schwann cells in neural sheath. First described by Verocay in 1908, these tumors usually occur in the third to fifth decade oflife, with no racial and gender difference. ${ }^{1,2}$ Schwannoma predominantly develop as solitary tumors, encapsulated, well-demarcated, homogenous masses, and non-infiltrating pattern with slow growth, sometimes associated with pain, paresthesia, and mechanical compression. ${ }^{1,2,3}$ Schwannoma located in the upper extremity and lower extremity account for $12-19 \%$ and $13.5-17.5 \%$ of the cases. In the lower extremity, schwannoma of the sciatic nerve is uncommon and only accounts for $1 \%$ of all schwannoma. ${ }^{1,4}$

\section{Case}

A 78-years-old woman presented to the outpatient clinic of the Department of
Neurosurgery, Semen Padang Hospital, in 2019. She complained about the pain in her slowly growing mass on the right popliteal region. She also suffered from mild-moderate pain and intermittent paresthesia of right leg and foot. The patient emphasized that the mass has existed for 22 years and disrupted her daily activities in the last 6 months. There was no history of trauma or surgery. She was prescribed analgesic drug, physiotherapy, and neuropathic pain-related medications without any significant benefit. On physical examination, the solid mass was found to be mobile and palpable at the center of the right popliteal fossa, with size $3 \times 3 \mathrm{~cm}$ and with no fluctuation or bruit. There was no erythema, warmth, or ulceration. The sensory and motor function examination of the lower extremity presented normal results. Informed consent was obtained from the patient and ethical approval was obtained from the Committee of Ethics, Semen Padang Hospital, Padang, Indonesia.

Routine laboratory diagnostic tests and x-rays showed no specific findings. Therefore, magnetic resonance imaging (MRI) of the right
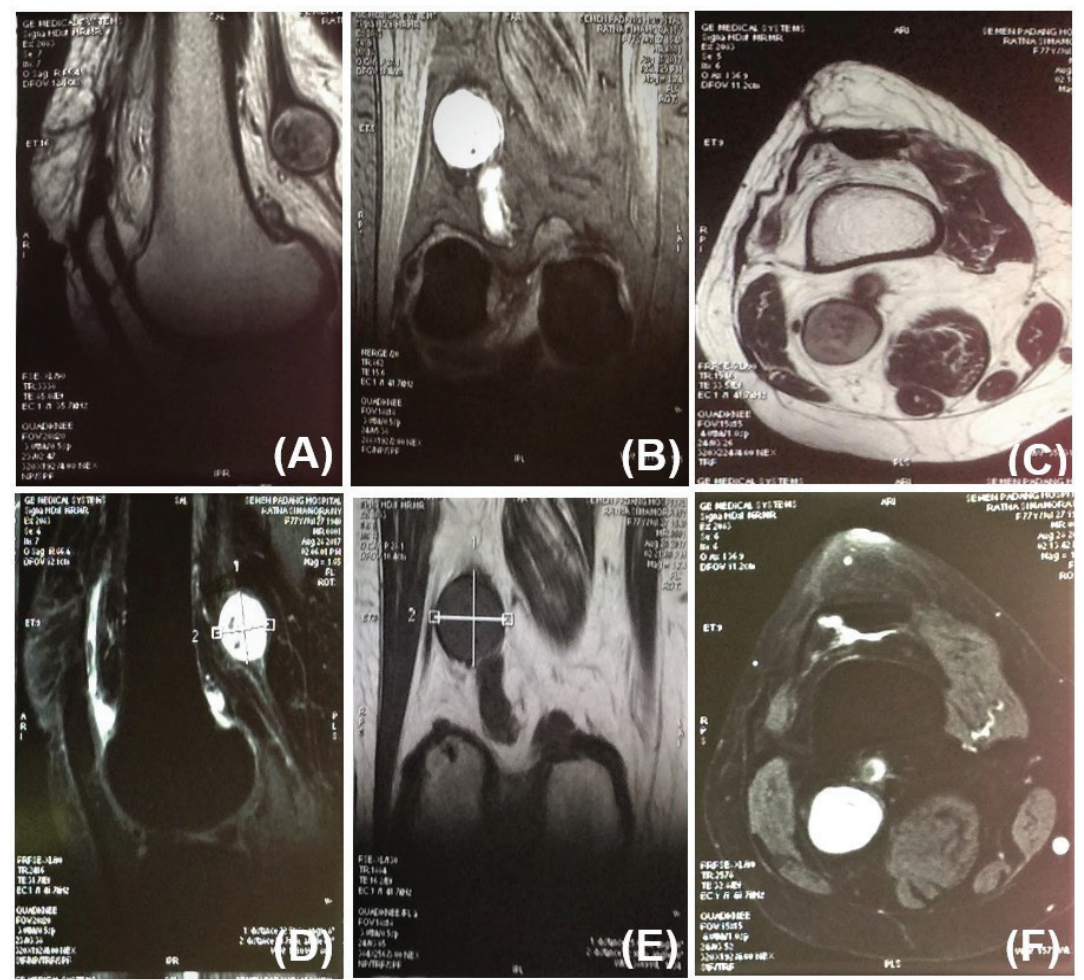

Figure 1 MRI Schwannoma of the Sciatic Nerve

Sagittal plane (A) T1W hypointense with slightly heterogeneous in the central area, coronal plane; (B) T2W hyperintense, axial plane; (C) T1W hypointense, slightly heterogeneous in the central area, sagittal plane;

(D) T2W hyperintense, coronal plane; (E) T1W hypointense, slightly heterogeneous, in the central area, axial (F) T2W hyperintense 

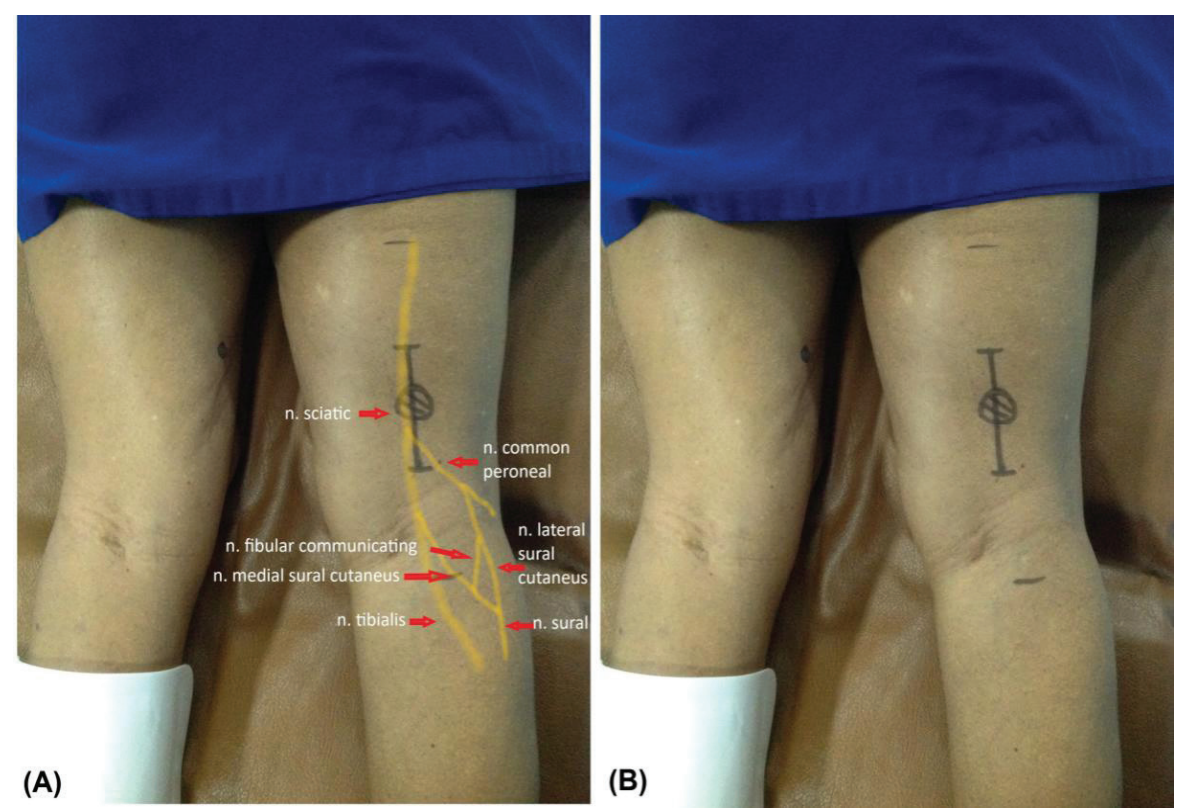

Figure 2 (A) Pre-operative Planning Anatomy of Sciatic Nerve and Branch, (B) Patient in the Prone Position with Longitudinal Skin Incision

distal femur-genu was obtained and showed well-defined solid tumors, T2W hyperintense, T1W hypointense slightly heterogeneous in the central area with a high signal in T2 fat-saturated, measuring $19.2 \times 20.2 \mathrm{~mm}$. Hence, the mass was suspected to be a peripheral nerve sheath tumor (Figure 1).
Microsurgical resection was performed with local peripheral nerve block and without intraoperative neurophysiological monitoring (IOM). The patient was awake in the prone position with longitudinal skin incision (Figure 2). Popliteal fossa was explored layer by layer and the tumor mass originating from distal
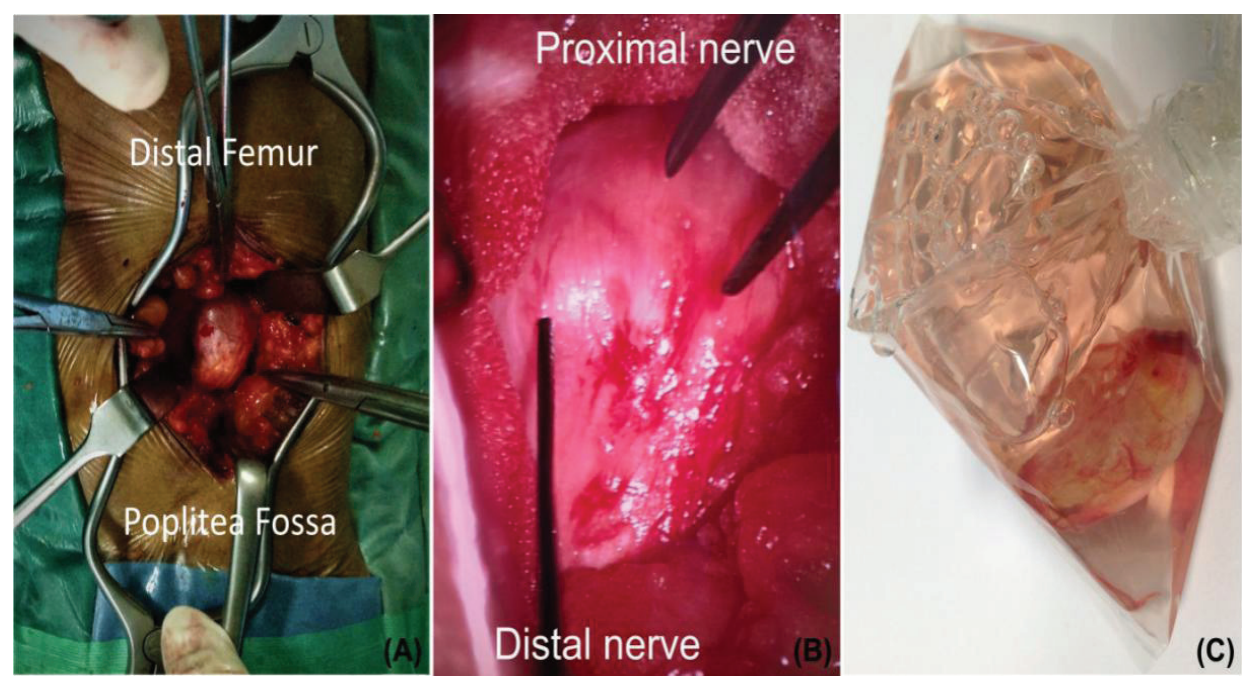

Figure 3 Intra-operative view: (A) Macroscopic Photography of Tumor, (B) Microscopic Photography with Microsurgical Resection Technique, (C) Tumor Resected in En-Bloc Form 


\section{A. Type I}

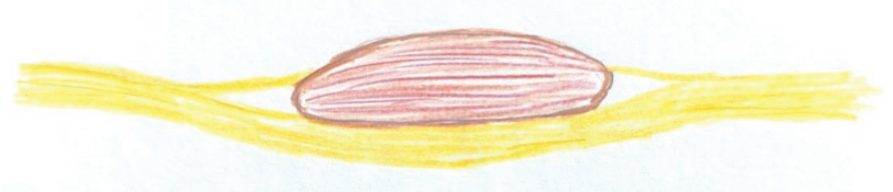

\section{B. Type II}

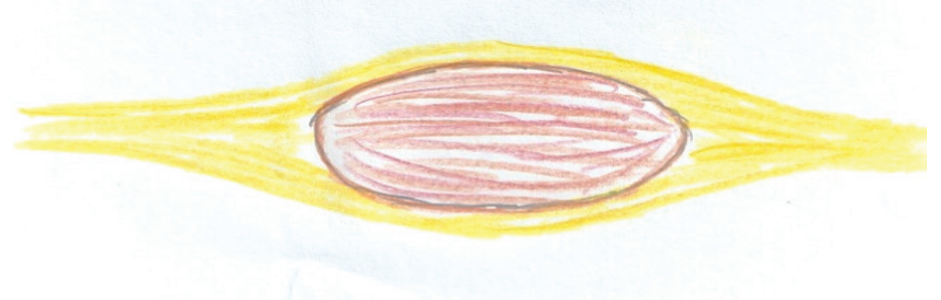

Figure 4 Two Types of Classification for the Relationship between Schwannoma and Nerve $^{7}$

sciatic nerve was dissected. The tumor was encapsulated and was taken out en-bloc by opening the epineurium or nerve sheath with a longitudinal incision to minimize damage to the sciatic nerve fascicles. The mass was then resected in en-bloc by sharp dissection using the microscope with no complication (Figure 3 ). The tumor mass was sent for histopathology examination and the result showed a capsulated form in the epineurium, characterized by Antoni A and Antoni B areas compatible with schwannoma.

Patient was discharged on the post-operation third day and a follow-up visit was scheduled in the third-week post-operation. At follow up, the patient reported a significant pain relief without any neurologic deficit.

\section{Discussion}

Schwannoma is the most common benign tumor of the nerve sheath and accounts for $5-8 \%$ of all benign soft tissue tumors. The involvement of the sciatic nerve is rare, with an incidence of less than one in 100 cases. ${ }^{1,45}$ The commonest age of affection is not similar in the case because the patient has been suffering the tumor for 22 years with slow growth and minimum complaint, causing a delay in treatment.

This tumor usually occurs as a solitary lesion and rarely occurs as multiple lesions, in which case the differential diagnosis is neurofibromatosis, in terms of signs and symptoms with genetic alterations. Hence, exclusion is needed.1,2,3 Clinically, a patient with sciatic nerve schwannoma presents with radicular pain which, more often than not, mimics other lumbar pathology till subsequently confirmed. ${ }^{4}$ In this present case, the patient had a solitary tumor mass present with radicular pain, was prescribed analgesic drugs, been in physiotherapy, and received neuropathic painrelated medications. Sometimes, it is impossible to differentiate the radicular pain in lower extremity as caused by schwannoma or lumbar pathology if the tumor is not apparent. When the complaint is not specific, confirmation with MRI needs is needed.

Surgical excision is the treatment of choice, but the decision to operate or observe will be based on the balance between the perceived risk of surgery and those associated with more conservative management. Patient's wish was 
also a determining factor. If surgical management is the best option for benign nerve sheath tumors, the goal of tumor removal must be aimed at minimum morbidity. Adequate visualization and successful removal will be achieved if the surgeon has detailed anatomical knowledge, performs good preoperative planning, and uses microsurgical resection techniques under appropriate magnification using microscope. , $^{6,7}$

According to $\mathrm{Li} \mathrm{X} \mathrm{et} \mathrm{al.,7} \mathrm{there} \mathrm{are} \mathrm{two} \mathrm{types}$ of classification for the relationship between schwannoma and nerve (Figure 4). In type I, the nerve stem and schwannoma were dissociated easily and the surgical strategy is only to strip out the tumor from the hammock-like nerve trunk microscopically while avoiding damaging the nerve trunk. Meanwhile, in type II the tumor is completely or mostly surrounded by the bundle of nerve. A longitudinal incision is made on the peripheral nerve sheath of the neuroma after the use of stimulation to identify a nonfunctioning area for entering. With microscopical sharp separation, the onion skin-like epineurial tissue layers are meticulously peeled out until the surface of the tumor is reached.Based on MRI examination for the case in this case study (Figure 1), the tumor nerve sheath was a type I classification tumor and the tumor capsule can be separated from the sheath nerve using microscopical sharp separation in a clear, gentle, and careful manner.

The use of intraoperative neurophysiological monitoring allows the evaluation of nerve fascicles involved with the tumor, distinguishing functional from non-functional nerves and, therefore, guiding the operative approach. The availability of such techniques will vary among institutions, and specialized staff and equipment are required. ${ }^{6,7}$ In this case study, in the absence of sophisticated technology, a modification was made with peripheral nerve block locally, so that the patient stayed awake during surgery. Direct observation and evaluation of sensory and motor responses when resecting the nerve sheath can be performed. The decision to perform a given method will also vary depending on the involved nerve and the experience of the surgeon. In this case, general anesthesia was not chosen based on the consideration of the patient's age and its complication related to general anesthesia.

Furthermore, the peripheral nerve blocks also have the advantage of providing analgesia and immobilization to the target limb while avoiding the side effects of general anesthesia, which include nausea or vomiting, sore throat, fatigue, and prolonged hospital stay. For our elderly patients, this approach decreases the incidence of postoperative delirium. ${ }^{8,9}$ Furthermore, the inhibition of the nociceptive impulse, which is responsible for muscle spasm following mobilization postoperatively, is hypothesized to improve pain relief and recovery for the procedure following a peripheral nerve block. Peripheral nerve blocks are associated with longer and improved analgesia on the day of the surgery than the first opioid consumption in regional anesthesia vs. general anesthesia as well as reducing the opioid dose and shorten the hospital stay. ${ }^{10}$

\section{References}

1. Gosk J, Gutkowska O, Urban M, Wnukiewicz W, Reichert P, Ziolkowski P. Result of surgical treatment of schwannoma arising from extremities. Biomed Res Int. 2015;2015:1-8.

2. Oz TT, Aktas B, Ozkan K, Ozturan B, Kilic B, Demiroglu M. A case of schwannoma of the common peroneal nerve in the knee. Orthop Rev. 2017;6825(9):19-20.

3. Komurcu E, Golge UH, Kaymaz B, Erdogan N. Popliteal schwannoma mimicking baker cyst: an unusual case. J Surg Case Rep. 2013;8:1-3.

4. Nahar S, Goyal A. A large schwannoma of sciatic nerve-a case report. J Peripheral Nerve Surg. 2018;2(1):86-9.

5. Kralick F, Koenigsberg R. Sciatic in a patient with unusual peripheral nerve sheath tumors. Surg Neurol. 2006;66(6):634-7.

6. Ball JR, Biggs MT. Operative steps in management of benign nerve sheath tumors. Neurosurg Focus. 2007;22(6):1-4.

7. Li X, Zhong G, Xu X, Wang K, Zhu Y, Qi X, et al. Surgical strategies for peripheral nerve schwannoma based on the intraoperative neurophysiological monitoring. Laparoscopic Endoscopic Robotic Surg. 2019;2(3):65-9.

8. Strøm C, Rasmussen LS, Sieber FE. Should general anaesthesia be avoided in the elderly?. Anaesthesia 2014;69(Suppl 1):3544.

9. Patel V, Champaneria R, Dretzke J, Yeung J. Effect of regional versus general anaesthesia on postoperative delirium in elderly patients undergoing surgery for hip fracture: a systematic review. BMJ Open 2018;8(12):e020757. 
J Henky \& A Faried: Functional Recovery of Rare Case of Sciatic Nerve Schwannoma with Peripheral Nerve Block

10. Héroux J, Belley-Côté E, Echavé P, Loignon MJ, Bessette PO, Patenaude N, et al. Functional recovery with peripheral nerve block versus general anesthesia for upper limb surgery: a systematic review protocol. Syst Rev. 2019;8(1):273. 